\title{
Desain Tempat Sampah Edukatif dan Persuasif Membentuk Karakter Cinta Lingkungan Bagi Anak Usia Dini
}

\author{
Dwi Nurul Izzhati ${ }^{*}{ }^{1}$, Amalia ${ }^{2}$, Helmy Rahadian ${ }^{3}$ \\ 1,2Program Studi Teknik Industri, ${ }^{3}$ Program Studi Teknik Elektro, \\ Universitas Dian Nuswantoro, Jl. Nakula 1 No.15, Semarang \\ e-mail: ${ }^{* 1}$ dwi.nurul.izzhati@ dsn.dinus.ac.id, ${ }^{2}$ amalia@dsn.dinus.ac.id, \\ 3helmyrahadian@dsn.dinus.ac.id
} (artikel diterima: 11-04-2020, artikel disetujui: 07-07-2020)

\begin{abstract}
Abstrak
Pengembangan desain tempat sampah edukatif dan persuasif pada penelitian ini merupakan salah satu upaya dalam pendidikan anak usia dini (golden age), untuk membentuk pondasi karakter cinta lingkungan dan kesadaran membuang sampah sejak usia dini yang sangat diperlukan dibawa sampai dewasa. Sebagai salah satu upaya mendukung program pemerintah dalam membentuk karakter, sikap dan kualitas hidup sumber daya manusia, yang akhirnya timbul kesadaran dan mau bergerak sebagai usaha pelestarian, perbaikan dan menjadi keselamatan lingkungan jangka panjang. Untuk membuat desain tempat sampah edukatif dan persuasif perlu dicari persepsi konsumen terhadap objek yang diteliti, dengan menggunakan metode Conjoint analysis. Penentuan atribut (stimuli) secara spesifik dalam pengembangan spesifikasi karakteristik membagi konsep Edukasi dalam tiga faktor secara garis besar yaitu auditori, kinestasi, visual dan dikembangkan dalam beberapa variabel.Berdasarkan hasil kuesioner dengan menggunakan teknik multivariat dapat diketahui bahwa secara umum dari hasil penelitian responden lebih suka bentuk: lainnya, desain: karakter, audio: panjang (10-30 detik), kinestetik: otomatis.
\end{abstract}

Kata kunci: anak usia dini, desain, metode conjoint analysis, tempat sampah

\begin{abstract}
The development of educative and persuasive trash design in this study is one of the efforts in early childhood education (golden age), to form the foundation of environmental love character and awareness of disposing of garbage from an early age which is very necessary to be carried to adulthood. As one of the effort to support government programs ini shaping the character attitude and quality of life of human resources, which eventually arises awareness and is willing to move as an effort to preserve, improve and become a long-term environmental safety. To make the design of educative and persuasive trash bins, it is necessary to find the consumer's perception of the object under study, using the Conjoint analysis method. Determination of specific attributes (stimuli) in the development of characteristic specifications divides the concept of education in outline three factors namely

E-ISSN: 2303-1867 | P-ISSN: 2303-1476
\end{abstract}


auditory, kinestation, visual and developed in several variables. shape: other, design: character, audio: long (10-30 seconds), kinesthetic: automatic.

Keywords: conjoint analysis method, design, early childhood, trash can

\section{PENDAHULUAN}

Pendidikan Cinta Lingkungan adalah upaya strategis dan mempunyai peran penting dalam membentuk karakter, sikap dan kualitas hidup sumber daya manusia melalui pengetahuan, keterampilan sehingga kesadaran masyarakat semakin meningkat khususnya mengenai lingkungan yang akhirnya timbul kesadaran dan mau bergerak sebagai usaha pelestarian, perbaikan dan menjadi keselamatan lingkungan jangka panjang untuk generasi sekarang dan yang akan datang, seperti yang tertulis dalam Undang-undang Republik Indonesia No. 23 tahun 1997 tentang pengelolaan lingkungan hidup.

Dalam meningkatkan kesadaran lingkungan perlu adanya sistem yang terintegrasi, dimulai dengan membangun pondasi yang kuat, dari sumber daya manusia, peralatan penunjang/teknologi, metode serta lingkungan yang menunjang terwujudnya proses dan suasana pendidikan. Segala sesuatu yang berada disekitar kita baik lingkungan biotik berupa komponen makhluk hidup maupun lingkungan abiotik berupa komponen makhluk hidup yang berada disekitar kita (Dwiyatmo.Kus, 2007). Aktivitas makhluk hidup (manusia) akan menghasilkan sampah, sampah diartikan semua barang yang tidak terpakai lagi, baik dalam bentuk sampah organik maupun non organik. Tapi sampah bisa dipakai lagi kalau di kelola dengan prosedur yang benar (Basriyanta, 2007). Sampah bagi setiap orang memiliki kadar relatif dan pengertian yang berbeda sesuai dengan standar kehidupannya.

Pembentukan rangsangan pendidikan dan pembentukan pengalaman dimulai sejak anak usia dini(masa golden age), usia 0-6 tahun, menurut (Nuraini, 2009) usia ini menentukan karakter dan kepribadian anak. kemampuan psikis dan fisik berkembang cukup cepat sekali(Sit,Masganti, 2015), mempunyai pola khusus sesuai tingkat tumbuh kembangnya. Masa keemasan (golden age), dalam penelitian (Uce L, 2015) menyebutkan bahwa 50\% menunjukkan otak (kecerdasan) berkembang saat usia empat tahun, usia ini menunjukkan range perkembangan otak yang cukup tinggi karena usia 8 tahun range bertambah $30 \%$ dan perkembangan otak optimal 100\% ketika usia 18 Tahun.Anak usia dini mempunyai 12 kajian yang dipakai sebagai perencanaan dalam pengembangan pendidikan menurut Bredecam dkk dalam (Masitoh, 2005), diantaranya keingintahuan yang kuat serta daya fantasi tinggi. Dengan adanya kajian ini banyak aspek yang bisa dikembangkan terutama dalam pendekatan perencanaan pengembangan pendidikan

Dalam penelitian ini makna Edukatif dan Persuasif secara harfiah mengacu KBBI yaitu terkait pendidikan yang mampu membujuk secara halus supaya yakin apa yang disampaikan. Ditegaskan kembali pengembangan model persuasif pendidikan Edukatif terbagi menjadi 3, yaitu: 1).Auditori (memotivasi anak untuk belajar dengan musik), 2).Kinestasi (belajar dan bergerak), 3) Visual (penglihatan), dipakai dalam pengembangan variabel (stimuli) dalam penelitian ini (Alimut Hidayat, A.A, 2007).

Penilaian penerimaan konsumen (anak usia dini) terhadap produk serta fungsinya dilakukan dengan analisa conjoint (Eversheim ,Ed., 2009) Analisis ini mengasumsikan bahwa total suatu produk didapat dengan menjumlahkan kepuasan konsumen terhadap masing - masing variabel produk secara individual. Conjoint analysis menurut (Hair, 
dkk., 2006), pemahaman respondensi dari berbagai objek (servis, produk atau ide) dapat menggunakan teknik multivariat dengan cara menkombinasikan objek dari nilai evaluasi konsumen terbentuklah kombinasi dari beberapa atribut, Sehingga dapat dirumuskan desain tempat sampah edukatif dan persuasif membentuk karakter cinta lingkungan yang diinginkan konsumen (anak usia dini).

\section{METODE PENELITIAN}

Metode yang dipakai dalam penelitian ini adalah Metode Conjoint Analysis dimana metode ini sangat handal dalam mengembangkan desain produk, sehingga desain yang diharapkan sesuai dengan harapan konsumen. Adapun langkah - langkah penerapan Conjoint Analysis dalam penelitian ini adalah sebagai berikut:

\section{Menentukan karakter spesifikasi}

Objek yang diteliti diamati faktor-faktor spesifikasi dan level yang terlibat misal tempat sampah yang menjadi faktor diantaranya adalah warna, ukuran. Faktor tersebut diperinci lagi misalnya warna: merah, hijau, biru

\section{Mendesain Stimuli}

Stimuli adalah mengkombinasi antara faktor dan level, misalnya tempat sampah warna merah ukuran kecil, tempat sampah warna merah ukuran sedang, tempat sampah warna merah ukuran besar. Jumlah stimuli yang dihasilkan $\mathrm{n} \mathrm{n} \mathrm{x}$....sampai $\mathrm{m}$

\section{Menyusun Kuesioner}

Kuesioner disusun untuk mencari pendapat responden terhadap produk tempat sampah edukatif dan persuasif yang diinginkan. Responden bisa menilai produk yang disukai dari skala nilai 1-10.

\section{Melakukan Proses Conjoint}

Dengan bantuan software conjoint dari data responden dapat diketahui desain yang diinginkan

\section{Analisa Proses Conjoint}

Pada proses analisa conjoint dianalisis lebih lanjut keinginan pengguna/konsumen.

\section{HASIL DAN PEMBAHASAN}

Hasil dan pembahasan dalam penelitian ini dilaksanakan sesuai dengan langkah-langkah penelitian, yaitu:

\section{a. Survey Pendahuluan}

Survey pendahuluan dilakukan untuk mengidentifikasi kebutuhan konsumen dengan melakukan penyebaran kuesioner bebas, berdasarkan hasil observasi dan wawancara didapat atribut pengembangan tempat sampah edukatif dan persuasif 
untuk anak usia dini adalah: Bentuk, Desain gambar sesuai trend, durasi audio persuasif, gerakan buka tutup tempat sampah.

\section{b. Menyusun Stimuli}

Sebelum dilakukan pengambilan kuesioner konjoint. Ditegaskan kembali pengembangan model persuasif, menurut (Alimut Hidayat, A.A, 2007).

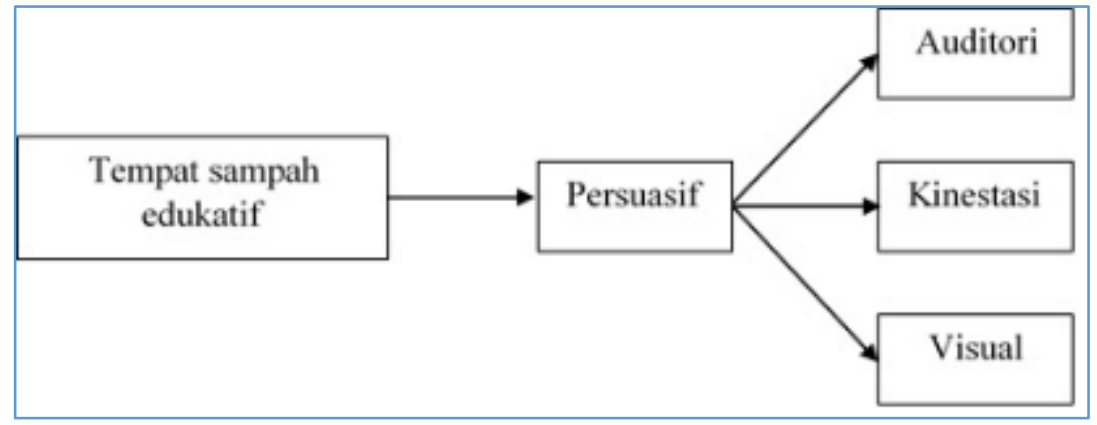

Gambar 1. Hubungan Edukatif dan Persuasif

Tabel 1. Atribut Desain dan Level Tempat Sampah

\begin{tabular}{cccl}
\hline No & Atribut & Taraf & \multicolumn{1}{c}{ Level } \\
\hline 1. & Bentuk & 1 & Kotak \\
& & 2 & Silinder \\
& & 3 & Lainnya \\
2 & Desain gambar sesuai trend & 1 & Karakter \\
& & 2 & Binatang \\
& & 3 & Simbul \\
3 & Durasi Audio persuasif & 1 & Pendek (1-5 detik) \\
& & 2 & Menengah (5-10 detik) \\
& & 3 & Panjang (10-30 detik) \\
4 & Gerakan buka tutup tempat & 1 & Manual \\
& sampah & 2 & Sentuh Otomatis \\
\hline
\end{tabular}

Berdasarkan atribut dan level pada tabel 1, akan disusun kombinasi produk (stimuli), penyusunan Stimuli berdasarkan Orthogonal Array dalam sofware SPSS. Hasil yang didapat dalam penggunaan Orthogonal Array adalah sebagai berikut:

Tabel 2. Orthogonal Plan Tempat Sampah Edukatif

\begin{tabular}{ccllll}
\hline & $\begin{array}{c}\text { Card } \\
\text { ID }\end{array}$ & Bentuk & Desain & \multicolumn{1}{c}{ Durasi_Audio } & \multicolumn{1}{c}{$\begin{array}{c}\text { Buka }- \\
\text { Tutup }\end{array}$} \\
\hline 1 & 1 & Lainnya & Simbol & Panjang (10-30 detik) & Manual \\
2 & 2 & Kotak & Simbol & Menengah (5-10 detik) & Manual \\
3 & 3 & Kotak & Binatang & Panjang (10-30 detik) & Sentuh \\
& & & & & Otomatis
\end{tabular}




\begin{tabular}{ccccll}
\hline & $\begin{array}{c}\text { Card } \\
\text { ID }\end{array}$ & Bentuk & Desain & \multicolumn{1}{c}{ Durasi_Audio } & $\begin{array}{c}\text { Buka - } \\
\text { Tutup }\end{array}$ \\
\hline 4 & 4 & Silinder & Simbol & Pendek (1-5 detik) & $\begin{array}{l}\text { Sentuh } \\
\text { Otomatis } \\
\end{array}$ \\
& 5 & Lainnya & Binatang & Pendek (1-5 detik) & Manual \\
5 & 6 & Silinder & Binatang & Menengah (5-10 detik) & Manual \\
6 & 7 & Kotak & Karakter & Pendek (1-5 detik) & Manual \\
7 & 8 & Silinder & Karakter & Panjang (10-30 detik) & Manual \\
8 & & Lainnya & Karakter & Menengah (5-10 detik) & Sentuh \\
& & & & Otomatis \\
\hline
\end{tabular}

\section{c. Menyusun Kuesioner}

Penyusunan kuesioner Conjoint didasarkan pada pengembangan desain dari atribut dan level tabel - 2, untuk mengetahui skor/rating pilihan dari konsumen. Konsumen disini adalah anak usia dini usia 0-6 th yang didampingi orang tua dalam pengisian dan beberapa guru Paud dan TK, Jumlah responden yang diambil sebanyak 71 responden .

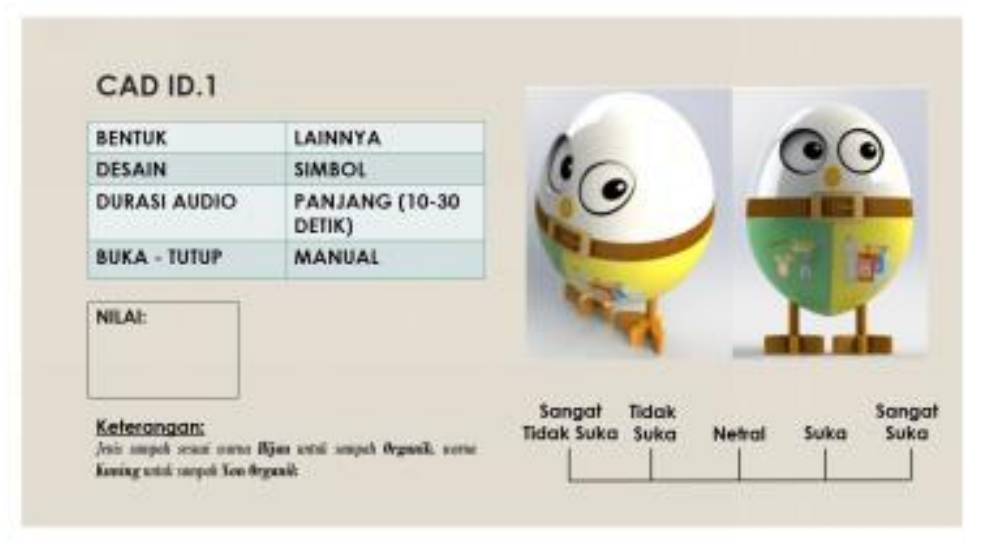

Gambar 2. Contoh Kuesioner

Kuesioner menunjukkan masing-masing profil untuk dinilai oleh responden dengan rentang 1-10. Penilaian ini dinilai sangat mudah dan sederhana sesingga mudah dimengerti responden.

Responden diedukasi bahwa produk yang dinilai mempunyai bentu,desai,durasi audio, buka tutup sesuai kodenya CAD ID 1, CAD ID 2, CAD ID 3, CAD ID 4, CAD ID 5, CAD ID 6, CAD ID 7, CAD ID 8, CAD ID 9 dari hasil pengamatan responden bisa menyatakan Sangat Suka, Suka, Netral, Tidak Suka, Sangat Tidak Suka yang di konversi dalam skala. 


\section{d. Melakukan Proses Conjoint}

Proses Conjoint dilakukan dengan bantuan perangkat lunak SPSS, sehingga mampu menunjukkan nilai pentingnya setiap level dan nilai korelasinya dengan menggunakan SPSS untuk setiap responden dan secara keseluruhan.

Tabel 3. Overall Statistics Utilities

\begin{tabular}{llrr}
\hline \multirow{2}{*}{ Bentuk } & Kotak & $\begin{array}{r}\text { Utility } \\
\text { Estimate }\end{array}$ & $\begin{array}{c}\text { Std. } \\
\text { Error }\end{array}$ \\
& Silinder & -.170 & .177 \\
& Lainnya & -.495 & .177 \\
Desain & Karakter & .665 & .177 \\
& Binatang & .651 & .177 \\
& Simbol & -.381 & .177 \\
Audio & Pendek (1-5 detik) & -.271 & .177 \\
& Menengah (5-10 detik) & -.038 & .177 \\
& Panjang (10-30 detik) & -.052 & .177 \\
Kinestetik & .090 & .177 \\
& Manual & -.745 & .132 \\
& Otomatis & .745 & .132 \\
& & 6.565 & .132 \\
\hline
\end{tabular}

Tabel 4. Averaged Importance Score

\begin{tabular}{llll}
\hline Bentuk & Desain & Audio & Kinestetik \\
\hline 27.614 & 24.672 & 24.976 & 22.737 \\
\hline
\end{tabular}

\section{KESIMPULAN}

\subsection{Kesimpulan}

Kesimpulan dari penelitian ini terkait "Pengembangan Desain Tempat Sampah Edukatif Dan Persuasif Dalam Membentuk Pendidikan Karakter Cinta Lingkungan Bagi Anak Usia Dini” adalah sebagai berikut:

1. Persepsi konsumen terhadap pengembangan desain dapat ditentukan kesukaan dari responden terhadap suatu level pada masing-masing atribut.Semakin tinggi nilai utilities semakin senang responden terhadap desain tersebut. Secara umum dari hasil penelitian responden lebih suka Bentuk: lainnya, Desain: Karakter, Audio: Panjang (10-30 detik), Kinestetik: Otomatis.

2. Desain Gambar yang direkomendasikan sesuai persepsi konsumen adalah karakter tempat sampah Apollo (pesawat ruang angkasa), tempat sampah warna hijau untuk organik dan tempat sampah kuning untuk anorganik, dengan buka tutup otomatis, disertai dengan bunyi-bunyian (audio) ucapan menyapa halo dan terimakasih, disertai suara musik yang sifatnya mengajak untuk cinta lingkungan. 


\subsection{Saran}

Saran dalam penelitian ini adalah perlu adanya kuesioner lanjutan terkait desain yang telah dihasilkan serta produk yang akan dibuat juga perlu memperhatikan aspek ergonomi.

\section{DAFTAR PUSTAKA}

Alimut Hidayat, A.A, 2007, Siapa Bilang Anak Sehat Pasti Cerdas, 6 Kunci Sukses Mempersiapkan Anak Tumbuh Sehat dan Cerdas. Elex Media Komputindo, Gramedia Grup, Jakarta

Basriyanta, 2007, Memanen Sampah, Kanisius, Yogyakarta.

Dwiyatmo, Kus., 2007, Pencemaran Lingkungan dan Penanganannya, Citra Aji Parama, Yogyakarta.

Eversheim (Ed.)., 2009, Innovation management for technical products-Systematic and integrated product development and production planning, Springer, Berlin.

Hair, dkk.,2006, Multivariate Data Analysis. Pearson International Edition Edition 6. New Jersey.

Nuraini, 2009, Analisis Pengaruh Kualitas Produk, Kualitas Pelayanan, Desain Produk, Harga Dan Kepercayaan Terhadap Loyalitas Pelanggan. Skripsi Fakultas Ekonomi Universitas Diponegoro.

Masitoh, dkk.,2004, Strategi Pembelajaran TK. Universitas Terbuka, Jakarta.

Undang-Undang Republik Indonesia Nomor 20 Tahun 2003 Tentang Sistem Pendidikan Nasional, Pasal 1. ayat 1.

Sit, Masganti., 2015, Psikologi Perkembangan Anak Usia Dini. Jilid. 1, Perdana Publishing, Medan

Uce, L., 2015, Masa Efektif Merancang Kualitas Anak. Jurnal Pendidikan Anak Bunayya. No.2, Vol.1, 77-92, https://jurnal.ar-raniry.ac.id/index.php/bunayya/ article/view/1322/982 